\title{
Performance Analysis of Recuperators of Two Oil Fired Aluminium Melting Furnaces
}

\author{
Ankur Kumar Pal ${ }^{1}$, Satyendra Singh ${ }^{2}$, Ravi Kumar ${ }^{3}$ \\ ${ }^{1}$ (Mechanical Engineering Department, Bipin Tripathi Kumaon Institute of Technology, Dwarahat, Almora, \\ Uttarakhand, India) \\ ${ }^{2}$ (Mechanical Engineering Department, Bipin Tripathi Kumaon Institute of Technology, Dwarahat, Almora, \\ Uttarakhand, India) \\ ${ }^{3}$ (Mechanical Engineering Department, Bipin Tripathi Kumaon Institute of Technology, Dwarahat, Almora, \\ Uttarakhand, India)
}

\begin{abstract}
This paper presents the performance analysis of the recuperators of two oil fired aluminium melting furnaces for the loading and melting condition. The melting capacities of the furnaces are $750 \mathrm{~kg}$ and $500 \mathrm{~kg}$. The operating conditions for the furnaces during loading and melting conditions are varied every 10 minutes with respect to the variation in load in the furnace. Each variation corresponds to a state, thus each condition has 4 states. The mass flow rates and temperatures at each state during melting and loading condition are estimated for both he furnaces. Corresponding operating parameters are calculated for each furnace for loading and melting condition. Subsequently, performance parameters are calculated. Then the performance of the recuperator is compared and analyzed for each condition and both the furnaces. An experimental comparative study is presented for the loading and melting conditions and also for both the furnaces.
\end{abstract}

Keywords: Recuperator, melting condition, loading condition, furnace

\section{Introduction And Literature Review}

Recuperators are one of the important components in the engineering plants and systems. So the construction and design of recuperators is very vital for the proper functioning of such systems. A recuperator is a heat exchanger to transfer heat from a hot fluid to cold fluid across a wall. The main requirement for a recuperator is that it should be able to transfer the heat with a very high effectiveness. Stoitchkov and Dimitrov (1997) examined Effectiveness of cross flow plate heat exchanger for indirect evaporative cooling. Lunsford (1998) carried out a study on increasing the heat exchanger performance. Aquaro and Pieve (2006) have given an overview of recent high temperature heat exchangers technology developments, both in the thermal-fluid dynamic innovative solutions and in the materials. Navarro and Gomez (2007) has studied and analysed a mathematical model for cross-flow heat exchangers with complex flow arrangements for determining $\varepsilon$-NTU relations is presented in this work. Guo et al. (2010) examined effectiveness-thermal resistance method for heat exchanger design and analysis. Gherasim et al. (2011) experimental investigation Heat transfer and fluid flow in a plate heat exchanger. Bahadori (2011) examined Simple method for estimation of effectiveness in one tube pass and one shell pass counter-flow heat exchangers. Cabezas-Gómez et al. (2012) analysis of a new cross flow heat exchanger flow arrangement -Extension to several rows. Buckinx et al. (2013) examined thermal design and optimization of small-scale high effectiveness cross-flow heat exchangers. Yang et al. (2013) examined experimental analysis of the influence of wall axial conduction on gas-to-gas micro heat exchanger effectiveness. Awad et al. (2013) examined Effectiveness-NTU relations for parallel flow heat exchangers. Hua el al. (2013) examined Performance study of a ground heat exchanger based on the multi pole theory heat transfer model. Cadavid et al. (2013) investigate experimental and numerical analysis Heat transfer model in recuperative compact heat exchanger type. Bari and Hossain (2013) investigated waste heat recovery from a diesel engine using shell and tube heat exchanger. Engel et al. (2013) has investigated the finned-tube heat exchangers which are frequently used in industry for gas-to-liquid heat transfer.

\section{Objective Of Present Work}

The objective of this paper is to analyze and compare the performance of the recuperator for loading and melting condition for both the furnaces and to study the effect of waste heat input, actual heat transfer and air-fuel ratio of burner on the effectiveness of recuperator.

\section{Experimental Setup}

The various equipment and instruments used in experiment are recuperator, blower, furnace, laser gun, pyrometer, flow meter, vane probe. Recuperators recover exhaust gas waste heat in medium to high temperature applications. The two dimensional layout of the recuperator is shown in Fig. 1. 


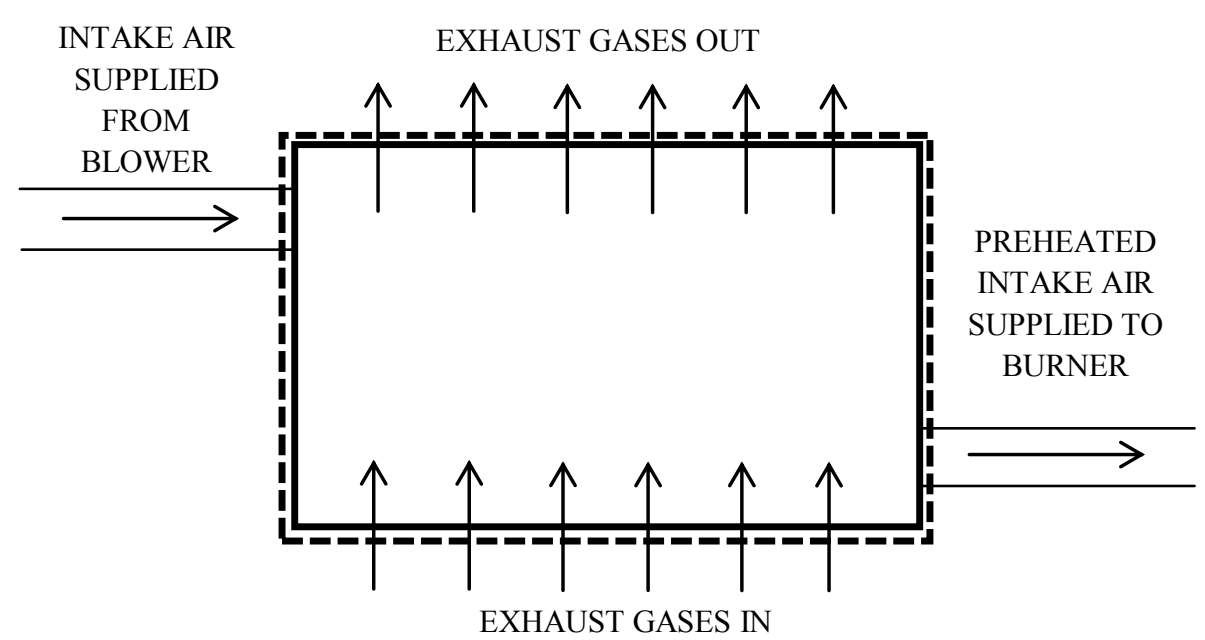

Fig.1 Layout of recuperator

The blower is of centrifugal type with radial blades. The performance analysis is carried on two oil fired aluminium melting furnaces. The capacity of furnace 1 is $750 \mathrm{~kg}$ and the capacity of furnace 2 is $500 \mathrm{~kg}$. Laser gun measures temperature from a distance. Pyrometer is an instrument for measuring temperature. Flow meters are used in fluid systems to indicate the rate of fluid flow. A vane anemometer is a type of instrument that combines two instruments, a wind vane and an anemometer, into one unit. By combining the two instruments into one unit, it is possible to measure both speed and the directional component of wind along with any changes in either component as they occur. The layout of furnace setup is displayed in Fig. 2.

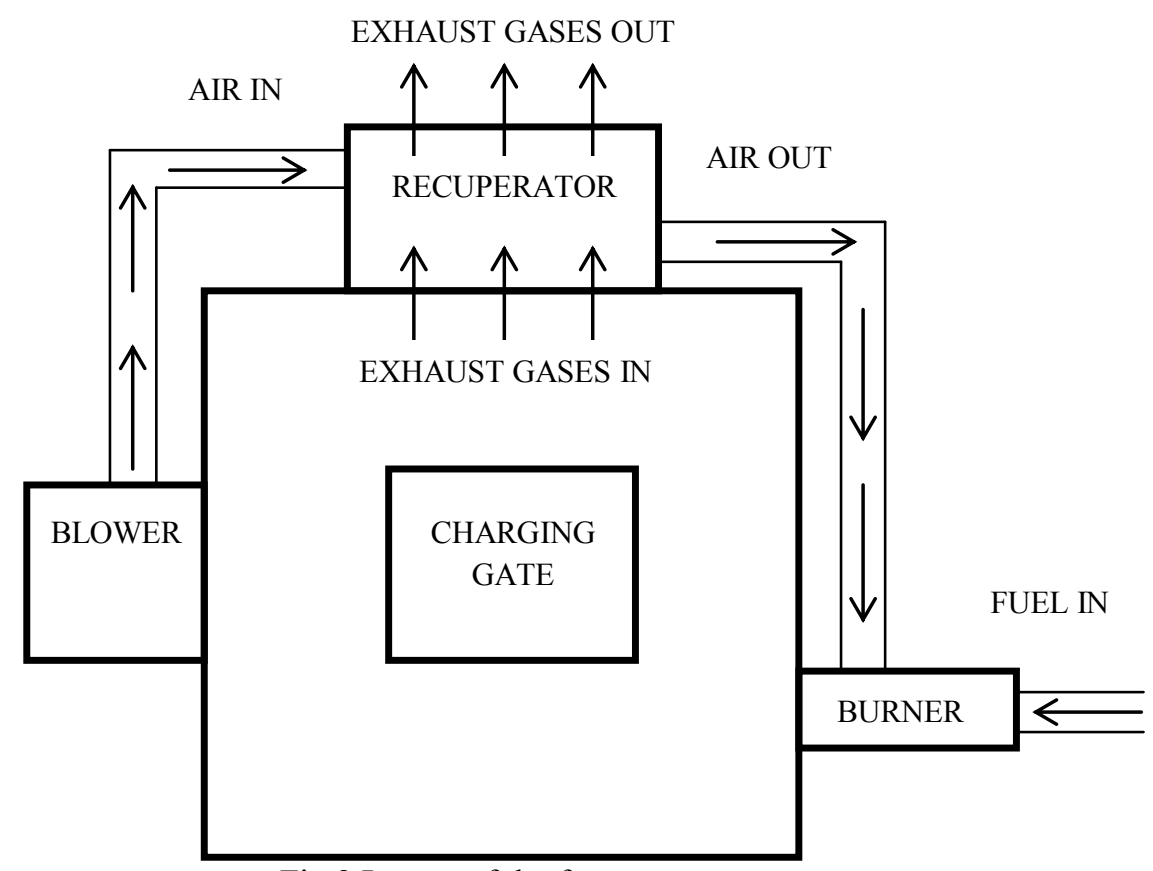

Fig.2 Layout of the furnace setup

\subsection{Loading Condition}

\section{Methodology}

Loading condition is the one in which the charge is loaded in the furnace through charging gate. During loading condition the charging gate of the furnace is opened for loading the material.

Now, effectiveness for loading condition:

$$
\begin{gathered}
\varepsilon=\frac{\dot{\mathrm{Q}}_{\mathrm{actual}}}{\dot{\mathrm{Q}}_{\max }} \\
\varepsilon=\frac{\mathrm{C}_{\mathrm{a}}\left(\mathrm{T}_{\mathrm{a}, \text { out }}-\mathrm{T}_{\mathrm{a}, \text { in }}\right)}{\mathrm{C}_{\min }\left(\mathrm{T}_{\mathrm{e}, \text { in }}-\mathrm{T}_{\mathrm{a}, \text { in }}\right)}=\frac{\mathrm{C}_{\mathrm{e}}\left(\mathrm{T}_{\mathrm{e}, \text { in }}-\mathrm{T}_{\mathrm{e}, \text { out }}\right)}{\mathrm{C}_{\min }\left(\mathrm{T}_{\mathrm{e}, \text { in }}-\mathrm{T}_{\mathrm{a}, \text { in }}\right)}
\end{gathered}
$$




$$
\varepsilon=\frac{\dot{\mathrm{m}}_{\mathrm{a}} \mathrm{C}_{\mathrm{p}, \mathrm{a}}\left(\mathrm{T}_{\mathrm{a}, \text { out }}-\mathrm{T}_{\mathrm{a}, \text { in }}\right)}{\mathrm{C}_{\min }\left(\mathrm{T}_{\mathrm{e}, \text { in }}-\mathrm{T}_{\mathrm{a}, \text { in }}\right)}=\frac{\dot{\mathrm{m}}_{\mathrm{e}} \mathrm{C}_{\mathrm{p}, \mathrm{e}}\left(\mathrm{T}_{\mathrm{e}, \text { in }}-\mathrm{T}_{\mathrm{e}, \text { out }}\right)}{\mathrm{C}_{\min }\left(\mathrm{T}_{\mathrm{e}, \text { in }}-\mathrm{T}_{\mathrm{a}, \text { in }}\right)}
$$

4.1.1 Estimation Of Temperatures In Loading Condition

(a) Inlet Temperature of Intake Air

(b) Outlet Temperature of Intake Air

$$
\mathrm{T}_{\mathrm{a}, \text { in }}=\mathrm{T}\left(\mathrm{r}_{2}\right)+\frac{\mathrm{h}}{\mathrm{K}_{\mathrm{p}}}\left(\mathrm{T}\left(\mathrm{r}_{2}\right)-\mathrm{T}_{\infty}\right) \cdot \mathrm{r}_{2} \cdot \ln \left(\frac{\mathrm{r}_{2}}{\mathrm{r}_{1}}\right)
$$

$$
\mathrm{T}_{\mathrm{a}, \text { out }}=\mathrm{T}\left(\mathrm{r}_{2}\right)+\frac{\mathrm{h}}{\mathrm{K}_{\mathrm{p}}}\left(\mathrm{T}\left(\mathrm{r}_{2}\right)-\mathrm{T}_{\infty}\right) \cdot \mathrm{r}_{2} \cdot \ln \left(\frac{\mathrm{r}_{2}}{\mathrm{r}_{1}}\right)
$$

(c) Inlet Temperature of Exhaust Gases

$$
\mathrm{T}_{\mathrm{e}, \text { in }}=\mathrm{T}(\mathrm{L})+\frac{\mathrm{hL}}{\mathrm{K}_{\mathrm{w}}}\left(\mathrm{T}(\mathrm{L})-\mathrm{T}_{\infty}\right)
$$

(d) Outlet Temperature of Exhaust Gases

$$
\mathrm{T}_{\mathrm{e}, \text { out }}=\mathrm{T}(\mathrm{L})+\frac{\mathrm{hL}}{\mathrm{K}_{\mathrm{w}}}\left(\mathrm{T}(\mathrm{L})-\mathrm{T}_{\infty}\right)
$$

(e) Temperature of Exhaust Gases From Charging Gate

The temperature of exhaust gases from charging gate is estimated by the pyrometer. The pyrometer is placed in front of the charging for recording the temperature of escape gases.

\subsubsection{Estimation of Mass Flow Rates}

(a) Mass Flow Rate of Intake Air

(b) Mass Flow Rate of Fuel

$$
\dot{\mathrm{m}}_{\mathrm{a}}=\rho_{\mathrm{a}} \mathrm{A}_{\mathrm{c}, \mathrm{a}} \mathrm{v}_{\mathrm{avg}, \mathrm{a}}
$$

$$
\dot{\mathrm{m}}_{\mathrm{f}}=\rho_{\mathrm{FO}} \dot{\mathrm{V}}
$$

(c) Mass Flow Rate of Escape Gases From Charging Gate

(d) Mass Flow Rate of The Exhaust Gases

$$
\dot{\mathrm{m}}_{\text {esacpe }}=\rho_{\mathrm{e}} \mathrm{A}_{\mathrm{c}, \mathrm{e}} \mathrm{V}_{\text {avg }, \mathrm{e}}
$$

$$
\dot{\mathrm{m}}_{\mathrm{e}}=\dot{\mathrm{m}}_{\mathrm{a}}+\dot{\mathrm{m}}_{\mathrm{f}}-\dot{\mathrm{m}}_{\text {escape }}
$$

\subsubsection{Estimation of Specific Heats During Loading Condition}

(a) Specific Heat of Intake Air

The specific heat of intake air is denoted by $\mathrm{C}_{\mathrm{p}, \mathrm{a}}$. The value of the specific heat of air is taken from the property tables.

(b) Specific Heat of Exhaust Gases

\subsection{Melting Condition}

$$
\mathrm{C}_{\mathrm{p}, \mathrm{e}}=\mathrm{mf}_{\mathrm{CO}_{2}} \cdot \mathrm{C}_{\mathrm{p}, \mathrm{CO}_{2}}+\mathrm{mf}_{\mathrm{H}_{2} \mathrm{O}} \cdot \mathrm{C}_{\mathrm{p}, \mathrm{H}_{2} \mathrm{O}}+\mathrm{mf}_{\mathrm{N}_{2}} \cdot \mathrm{C}_{\mathrm{p}, \mathrm{N}_{2}}
$$

After loading the charge in the furnace during loading condition, the charging gate of the furnace is closed and the metal is allowed to melt for the suitable time. This state of the furnace is known as melting condition. In the melting condition the loses from charging gate are not there and all the estimations of tempetarures and mass flow rates are similar to that in loading condition.

\section{Results And Discussion}

In the present study, the performance analysis of the recuperators of two oil fired aluminium melting furnaces is done for the loading and melting condition. The outer surface temperature and exhaust gas temperature during loading condition and melting condition for furnace 1 and furnace 2 are tabulated in Table 1 and Table 2 respectively. The performance of the recuperator is compared and analyzed at each condition for both the furnaces.

The variation of effectiveness with respect to the mass flow rate of fuel, mass flow rate of exhaust gases, the air fuel ratio and the actual heat transfer rate for furnace 1 in loading condition shown in Fig. 1-4 and in melting condition in Fig. 5-8 and for furnace 2 in loading condition and in melting condition are displayed in Fig. 9-12 and Fig. 13-16 respectively. The effectiveness of the recuperator increases with the increase in the mass flow rate of the fuel supplied, the mass flow rate of the exhaust gases and rate of actual heat transfer and with the decrease in the air fuel ratio. The effectiveness for the loading and melting condition has been compared for both furnaces in Fig. 17-18. The effectiveness of the recuperator increases during the loading condition, but it decreases during the melting condition. 
Table 1. Outer surface temperature and exhaust gas temperature during loading condition and melting condition for furnace 1

\begin{tabular}{|c|c|c|c|c|c|c|c|c|}
\hline \multirow[b]{2}{*}{ State } & \multicolumn{4}{|c|}{ Outer surface temperature, ${ }^{\circ} \mathrm{C}$} & \multicolumn{4}{|c|}{ Exhaust gas temperature, ${ }^{\circ} \mathrm{C}$} \\
\hline & Air inlet & Air outlet & $\begin{array}{l}\text { Exhaust } \\
\text { inlet }\end{array}$ & $\begin{array}{l}\text { Exhaust } \\
\text { outlet }\end{array}$ & Air inlet & Air outlet & $\begin{array}{l}\text { Exhaust } \\
\text { inlet }\end{array}$ & $\begin{array}{l}\text { Exhaust } \\
\text { outlet }\end{array}$ \\
\hline \multicolumn{9}{|c|}{ Loading condition } \\
\hline 1 & 188 & 250 & 307 & 205 & 188.08 & 250.12 & 308.35 & 205.85 \\
\hline 2 & 190 & 255 & 312 & 211 & 190.01 & 255.12 & 313.37 & 211.88 \\
\hline 3 & 191 & 261 & 316 & 215 & 191.09 & 261.12 & 317.39 & 215.90 \\
\hline 4 & 191 & 268 & 324 & 222 & 191.09 & 268.14 & 325.43 & 222.94 \\
\hline \multicolumn{9}{|c|}{ Melting condition } \\
\hline 1 & 190 & 293 & 340 & 221 & 190.01 & 293.14 & 341.51 & 221.93 \\
\hline 2 & 191 & 285 & 337 & 215 & 191.09 & 285.14 & 338.50 & 215.90 \\
\hline 3 & 190 & 276 & 332 & 209 & 190.01 & 276.13 & 333.47 & 209.87 \\
\hline 4 & 189 & 270 & 325 & 204 & 189.08 & 270.13 & 326.44 & 204.85 \\
\hline
\end{tabular}

Table 2. Outer surface temperature and exhaust gas temperature during loading condition and melting condition

\begin{tabular}{|c|c|c|c|c|c|c|c|c|}
\hline State & \multicolumn{4}{|c|}{ Outer surface temperature, ${ }^{\circ} \mathrm{C}$} & \multicolumn{4}{|c|}{ Exhaust gas temperature, ${ }^{\circ} \mathrm{C}$} \\
\hline 1 & 187 & 253 & 311 & 209 & 187.08 & 253.12 & 312.37 & 209.87 \\
\hline 2 & 189 & 258 & 317 & 214 & 189.08 & 258.12 & 318.40 & 214.90 \\
\hline 3 & 190 & 266 & 324 & 220 & 190.09 & 266.13 & 325.43 & 220.93 \\
\hline \multicolumn{9}{|c|}{ Melting condition } \\
\hline 1 & 189 & 301 & 343 & 224 & 189.08 & 301.14 & 344.53 & 224.95 \\
\hline 2 & 190 & 293 & 340 & 218 & 190.09 & 293.14 & 341.51 & 218.92 \\
\hline 3 & 189 & 285 & 336 & 213 & 189.08 & 285.14 & 337.49 & 213.89 \\
\hline 4 & 188 & 275 & 328 & 207 & 188.08 & 275.13 & 329.45 & 207.86 \\
\hline
\end{tabular}

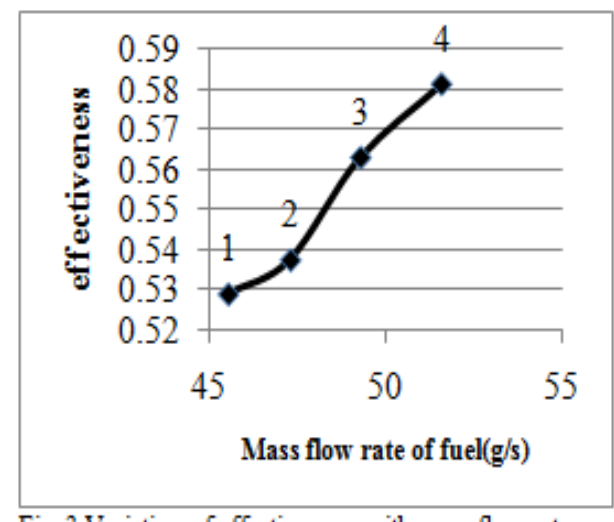

Fig. 3 Variation of effectiveness with mass flow rate of fuel for loading condition for furnace 1

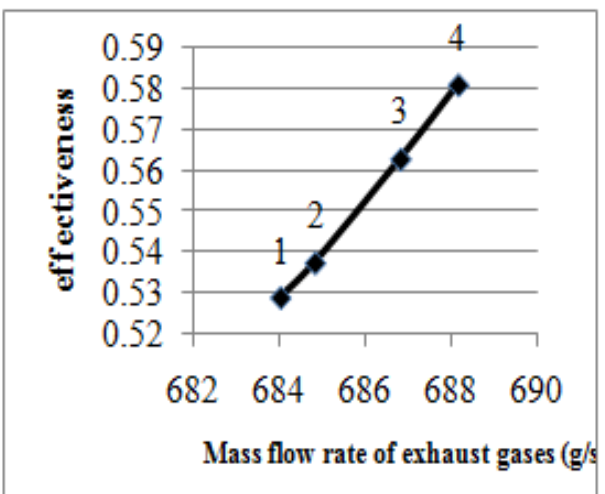

Fig. 4 Variation of effectiveness with mass flow rate of exhaust gases for loading condition for fumace 1

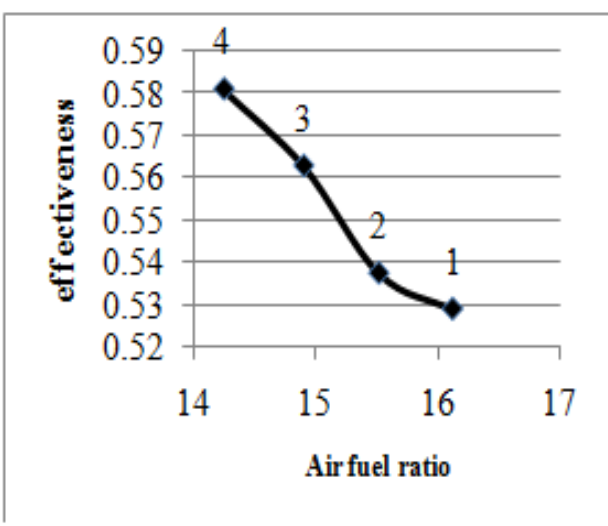

Fig. 5 Variation of effectiveness with air fuel ratio for loading condition for fumace 1

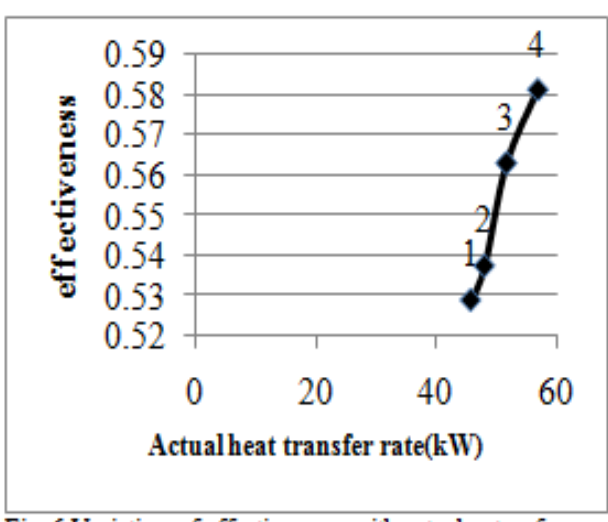

Fig. 6 Variation of effectiveness with actual rate of heat transfer for loading condition for furmace 1 


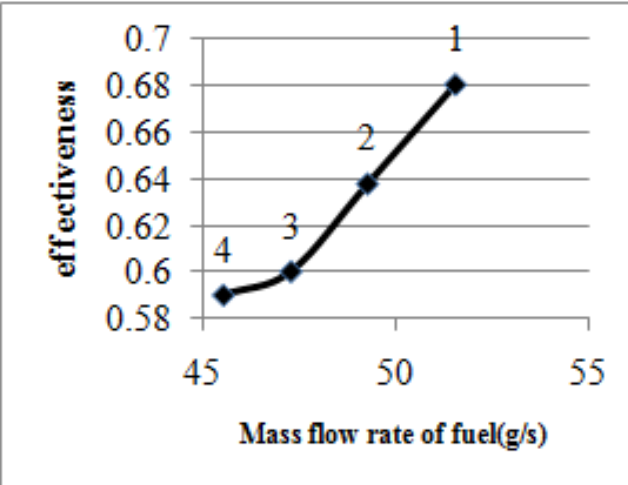

Fig. 7 Variation of effectiveness with mass flow rate of fuel for melting condition for furnace 1

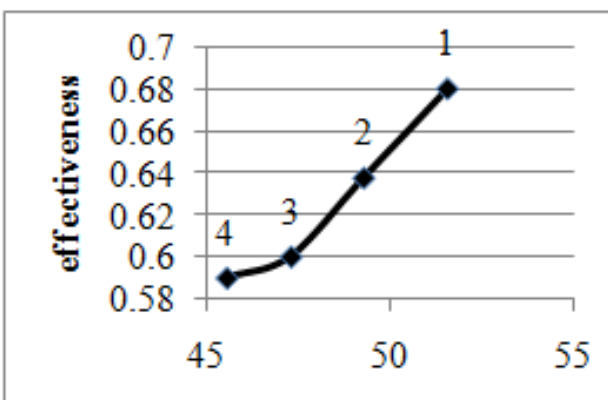

Mass flow rate of exhaust

Fig. 8 Variation of effectiveness with mass flow rate of exhaust gases for melting condition for furnace 1

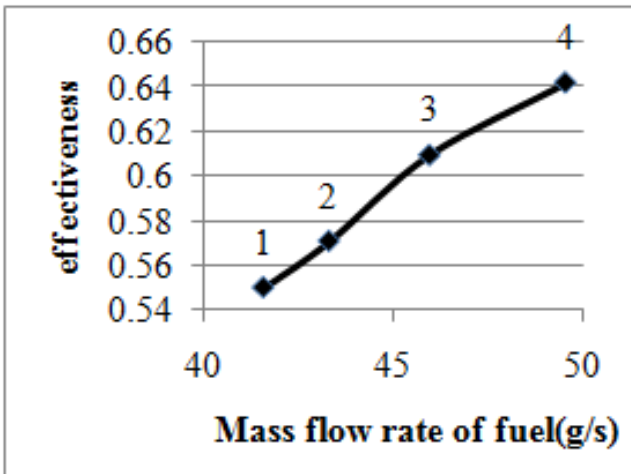

Fig. 11 Variation of effectiveness with mass flow rate of fuel in loading condition for furnace 2

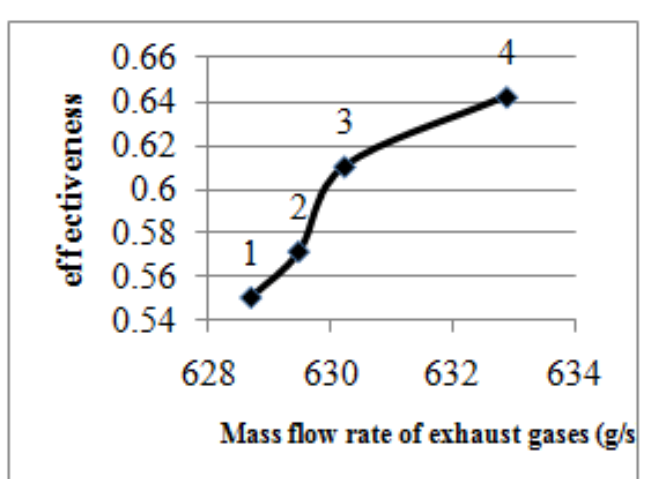

Fig. 12 Variation of effectiveness with mass flow rate of exhaust gases in loading condition for furnace 2

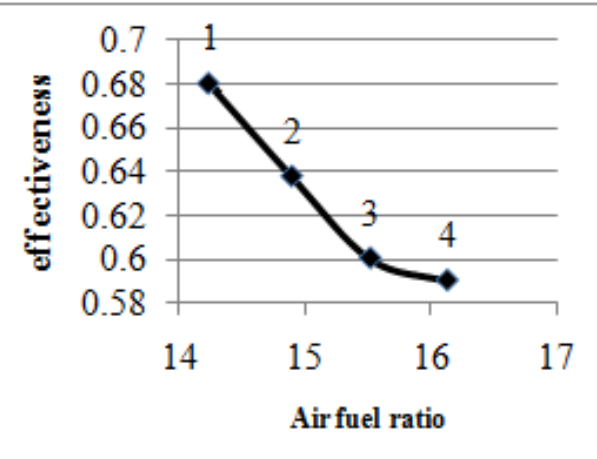

Fig. 9 Variation of effectiveness with air fuel ratio for melting condition for furnace 1

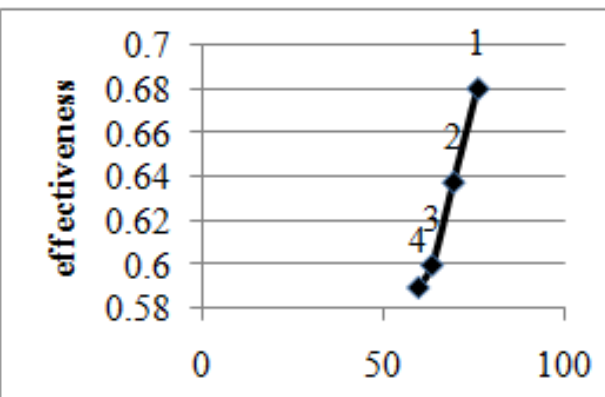

Actual heat transfer rate $(\mathrm{kW})$

Fig. 10 Variation of effectiveness with actual rate of heat transfer for melting condition for furnace 1

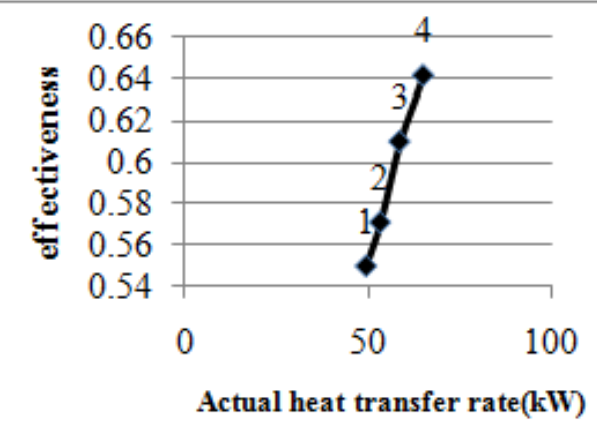

Fig. 14 Variation of effectiveness with actual rate of heat transfer in loading condition for fumace 2

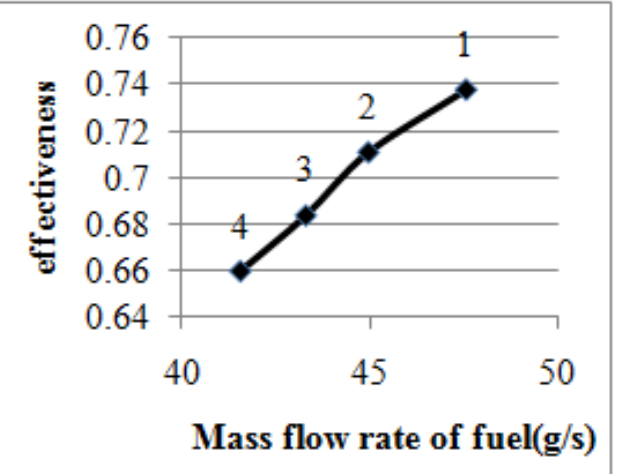

Fig. 15 Variation of effectiveness with mass flow rate of fuel in melting condition for furnace 2 


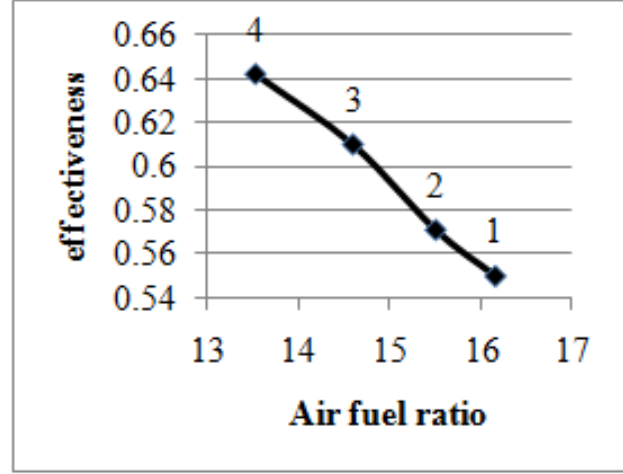

Fig. 13 Variation of effectiveness with air fuel ratio in loading condition for furmace 2

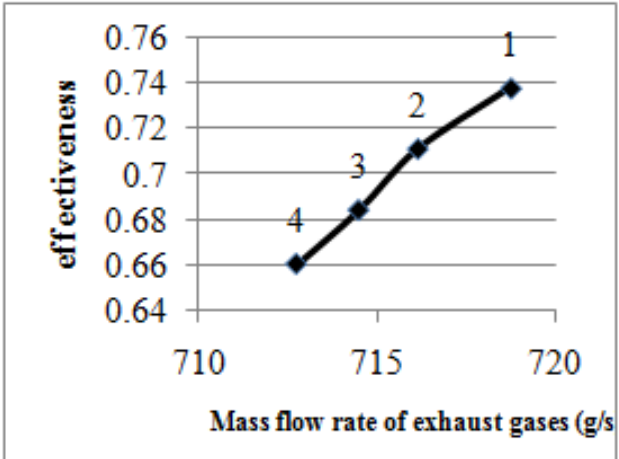

Fig. 16 Variation of effectiveness with mass flow rate of exhaust gases in melting condition for furnace 2

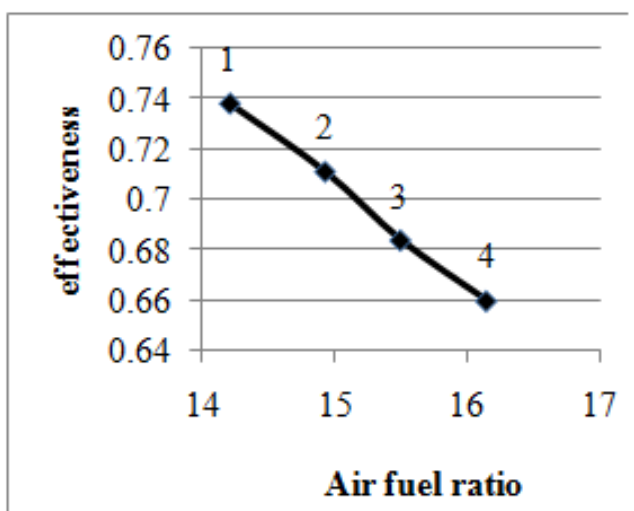

Fig. 17 Variation of effectiveness with air fuel ratio in melting condition for furmace 2

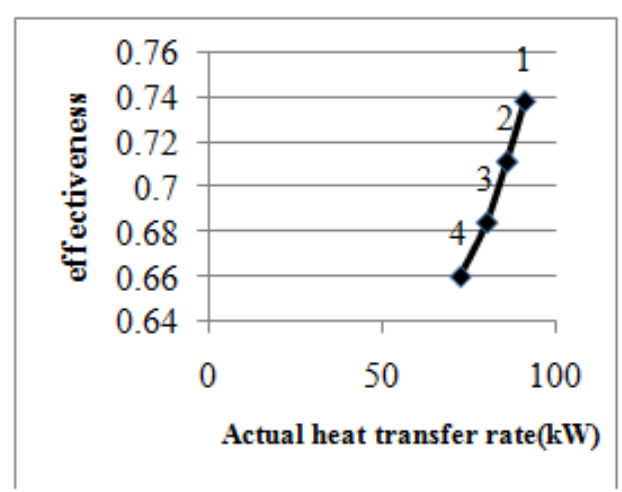

Fig. 18 Variation of effectiveness with actual rate of heat transfer in melting condition for fumace 2

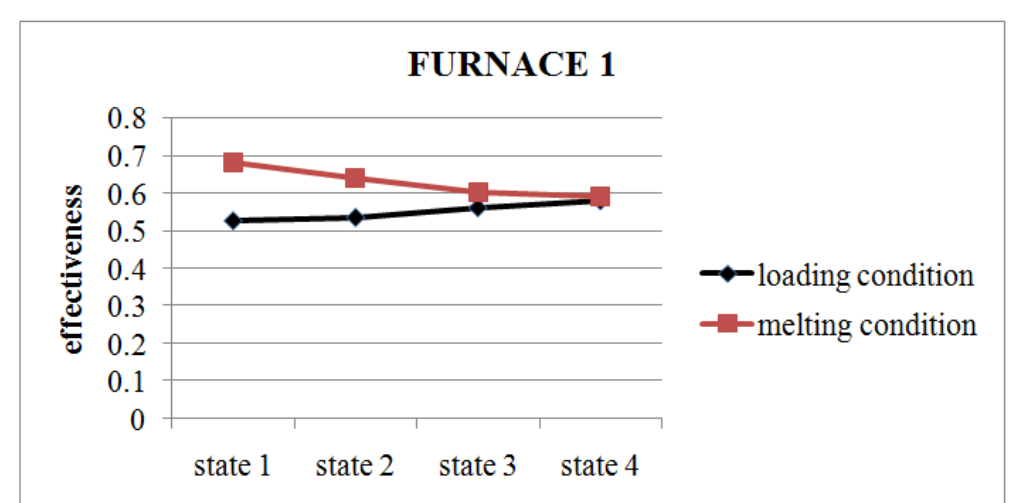

Fig. 19 Variation of effectiveness in loading and melting condition

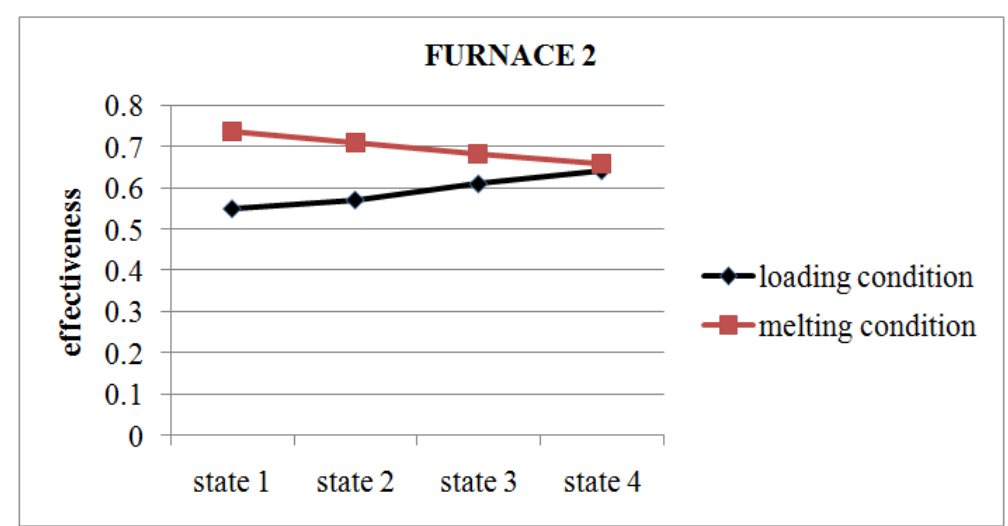

Fig. 20 Variation of effectiveness for loading and melting condition for furnace 2 


\section{Conclusion}

The performance analysis performed, provides a fundamental understanding of the working of recuperator for the waste heat recovery. The main findings of the present analysis are as follows:

- The effectiveness of the recuperators increase with the increase in mass flow rate of fuel.

- The effectiveness of the recuperators increase with the increase in mass flow rate of exhaust gases.

- The effectiveness of the recuperator increases during loading condition for both the furnaces.

- The effectiveness of the recuperator decreases during melting condition for both the furnaces.

- Both the furnaces have identical recuperator. The effectiveness of the recuperator of lower capacity

\section{References}

[1] Alireza Bahadori, 2011. Simple method for estimation of effectiveness in one tube pass and one shell pass counter-flow heat exchangers, Applied Energy, Vol. 88, pp 4191-4196

[2] Aquaro D. and Pieve M., 2005. High temperature compact heat exchangers: Performance of Advanced Metallic Recuperators for Power Plants, Fifth International Conference on Enhanced, Compact and Ultra-Compact Heat Exchangers: Science, Engineering and Technology, pp 238-246.

[3] Awad B.S. et al , 2013. Effectiveness-NTU relations for parallel flow heat exchangers: The effect of kinetic energy variation and heat leak from outside, International Journal Of Refrigeration, Vol. 36, pp 1557-1569

[4] Frithjof Engel, David Meyer, 2013. Experimental Characterization of the Thermal Performance of a Finned-tube Heat Exchanger, 35th New Zealand Geothermal Workshop: 2013 Proceedings

[5] Geert Buckinx et al , 2013. Thermal design and optimization of small-scale high effectiveness cross-flow heat exchangers, International Journal of Heat and Mass Transfer, Vol. 60, pp 210-220

[6] Iulian Gherasim et al, 2011. Heat transfer and fluid flow in a plate heat exchanger part I. Experimental investigation, International Journal of Thermal Sciences, Vol. 50, pp 1492-1498.

[7] Kevin M. Lunsford, 2006. Increasing Heat Exchanger Performance, Bryan Research and Engineering, Inc. - Technical Papers

[8] Luben Cabezas-Gómez et al , 2012. Analysis of a new cross flow heat exchanger flow arrangement -Extension to several rows, International Journal of Thermal Sciences, Vol. 55, pp 122-132

[9] Navarro1 H.A. and Cabezas-Gómez L.C., 2007. Effectiveness-NTU Computation with a Mathematical Model for Cross-flow Heat Exchangers, Brazilian Journal of Chemical Engineering, Vol. 24 , pp 509-521

[10] Pingfang Hua et al , 2013. Performance study of a ground heat exchanger based on the multipole theory heat transfer model, En ergy and Buildings, Vol. 65, pp 231-241

[11] Saiful Bari, Shekh N. Hossain, 2013. Waste heat recovery from a diesel engine using shell and tube heat exchanger, Applied Thermal Engineering, Vol. 61, pp 355-363

[12] Stoitchkov N. J. and Dimitrov G. I., 1998. Effectiveness of crossflow plate heat exchanger for indirect evaporative cooling, International Journal of Refrigeration, Vol. 21, pp 463-471

[13] Yahui Yang et al , 2014. Experimental analysis of the influence of wall axial conduction on gas-to-gas micro heat exchanger effectiveness, International Journal of Heat and Mass Transfer, Vol. 69, pp 17-25

[14] Yonatan Cadavid, Andrés Amell et al , 2013. Heat transfer model in recuperative compact heat exchanger type honeycomb: Experimental and numerical analysis, Applied Thermal Engineering, Vol. 57, pp 50-56

[15] Z.Y. Guo a et al , 2010. Effectiveness-thermal resistance method for heat exchanger design and analysis, International Journal of Heat and Mass Transfer, Vol. 53, pp 2877-2884 